OPEN ACCESS

Citation: A. Eruola (2021) Response of yam varieties to soil moisture regime in Southwestern Nigeria. Italian Journal of Agrometeorology (2): 3-14. doi: 10.36253/ijam-1324

Received: May 31, 2021

Accepted: July 18, 2021

Published: December 27, 2021

Copyright: (c) 2021 A. Eruola. This is an open access, peer-reviewed article published by Firenze University Press (http://www.fupress.com/ijam) and distributed under the terms of the Creative Commons Attribution License, which permits unrestricted use, distribution, and reproduction in any medium, provided the original author and source are credited.

Data Availability Statement: All relevant data are within the paper and its Supporting Information files.

Competing Interests: The Author(s) declare(s) no conflict of interest.

\section{Response of yam varieties to soil moisture regime in Southwestern Nigeria}

\author{
Abayomi Eruola \\ University of Agriculture, Abeokuta,Nigeria \\ E-mail: layosky@yahoo.com
}

\begin{abstract}
A field experiment was conducted on varietal response of white yam to moisture regime in Abeokuta. The experiment comprised three varieties of yam (Efuru, Ise-osi and Oniyere), three mulching options (grass, polythene and unmulched), and two planting dates (early and late). Treatments were replicated three times using RCBD lay-out. Model for selecting planting date involved relating potential evapotranspiration (PE) to precipitation $(\mathrm{P})$ in the form of $0.1 \mathrm{PE}<\mathrm{P}<0.5 \mathrm{PE}$, partitioned for attaining optimal planting date into early $\left\{\mathrm{T}_{1}=\Sigma(\mathrm{P}-0.1 \mathrm{PE}) \leq 0\right\}$ and late $\left\{\mathrm{T}_{2}=\Sigma(\mathrm{P}-0.5 \mathrm{PE})\right.$ $\leq 0\}$, respectively. For humid period defined by $\mathrm{P}>\mathrm{PE}$, the physiological parameters and moisture agro-climatic indices measured during phenological stages of yam grown were analyzed with respect to treatments. Result showed that $\mathrm{T}_{1}$ defined as $\Sigma(\mathrm{P}-0.1 \mathrm{PE})$ $\leq 10 \mathrm{~mm}$ appeared as the best model that significantly $(\mathrm{P}<0.05)$ influenced emergence rate, phenological growth and tuber yield. All yam varieties evaluated were suitable for planting with respect to yield. Efuru and Ise-osi synchronized perfectly with Actual Water Availability and produced good vegetative growth with LAI of 1.08 and 0.91 leading to higher tuber yield of 12 and 11.64 tonnes ha ${ }^{-1}$, respectively. Grass mulch had tuber yield, 4-6 tonnes ha-1 greater than the polythene and unmulched plots in all varieties. Mulching significantly $(\mathrm{P}<0.05)$ increased tuber yield, 6-8 tonnes ha ${ }^{-1}$ than the unmulched. Conclusively, early planting with grass mulch increased tuber yield.
\end{abstract}

Keywords: crop, evapotranspiration, Penman formula, yield, Actual Water Availability.

\section{INTRODUCTION}

Water supply in terms of annual rainfall total is not a constraint to crop production in Southwest Nigeria (Ofori, etal. 2014). However, the seasonal and spatial variations in rainfall to a great extent have effects on agricultural activities (Um et al., 2017; Gidey et al., 2018), as most farmers find it extremely difficult to accurately determine the reliable beginning of the rain vis-à-vis favorable weather condition to commence their agricultural activities because rainfall plays a crucial role in determining agricultural yields (Audu, 2012; Bhandari, 2013; Shiru et al., 2018). It is therefore necessary to implement methods of soil water conservation in farming operation to improve crop production and reduce food insecurity in Africa and in particular Nigeria (Tiamiyu et al., 2015). The soil water conservation provides 
the means of minimizing the amount of water lost from the soils through evaporation and transpiration or the combination, the evapotranspiration.Most of soil moisture conservation strategies are relatively low cost and complex in their approach, based on the presence of required materials and technical capacity locally. Many of the methods rely on providing some kind of cover for the soil to minimize evapotranspiration and direct soil exposure to heat and sun. Examples of methods for reducing excess soil moisture loss include spreading manure or compost over the soil, Mulching, conservation tillage, crop rotation, Green manuring, among others. The selection of a specific variety largely depend on the way in which planting date is managed to prevent incidence of failure of agricultural crops, replanting and ultimate low yield that have characterized the agricultural food crops production in Nigeria.

Yam is a tropical crop which has as many as 600 species, of which six are economically important staple species. Out of the six, Dioscorea rotundata (white yam) and Dioscorea alata (water yam) are the most common species in Nigeria (IITA, 2009; Zaknayiba and Tanko, 2013). Yam is in the class of roots and tubers that is a staple of the Nigerian and West African diet, which provides some 200 calories of energy per capita daily. Bearing in mind that soil moisture is essential for the survival of yam (Dioscorea rotundata) setts before the rain is established, it is imperative to determine accurately the reliable onsets and cessation of the rain vis-à-vis planting date of yam. Furthermore, the occurrence of wet- season- dry spells which may last for a few days to more than three weeks particularly during the full vegetative stage when evaporative demand is high is another serious limiting factor to yam production (Mulebekeet al., 2010). However, for location with good soil moisture retention, yam may manage to utilize soil moisture reserve contained in the pores of the soil, or upon the very limited reserve contained in its own tissue during dry spells between rains. Yam may also adapt physiologically or behaviorally to prevent temporary depletion of the stored tissue moisture in other to prevent impairment of normal physiological function that may cause irreversible damage and plant death. This is more so that yam is highly susceptible to dry spells that occur during the onset of the rains and particularly before the rain has fully established. Therefore, since yam is planted between the periods extending from around the cessation of the rains in a given year to the time of onset in the succeeding year, it implies therefore that as soon as germination starts, soil moisture become critical. To alleviate the problem of soil moisture, there is need for efficient soil moisture conservation strategy in other to optimize soil physical condition affecting the crop yield (Susha etal. 2014). Various techniques used by traditional farmers in modifying the on-farm microclimate and efficiency of such techniques in West Africa have been studied and reported (Kutugi, 2002; Okoh, 2004; Gbadebor, 2006; Maikasuwa and Ala, 2013; and Yanmin Yang et al. 2015). As reported by International Institute of Tropical Agriculture (IITA, 1995; IITA, 2013), mulching is very important in yam cultivation. Nahanga and Verra (2015) reported that majority of the traditional yam farmers in West Africa use different mulching materials for yam cultivation. These materials range from dry grass, palm front to wood shaving. Of recent however, the IITA and some less conservative farmers were already using polythene plastic mulch in production of seed yam. However, research into the use of polythene plastic mulch in yam production is not widespread in Nigeria. Hence, for successful cropping, it is pertinent to relate the period of effective water availability to the phonological characteristic of yam variety in other toinvestigating the response of white yam to soil moisture variation. The investigation was based on assessment of planting dates, mulching options and mulching materialson the growth and yield of white yam.

\section{MATERIALS AND METHODS}

\section{Description of study area}

This study was conducted at the Teaching and Research farm of University of Agriculture along Alabata road, Abeokuta $\left(7^{\circ} 15^{\prime} \mathrm{N}, 3^{\circ} 25^{\prime} \mathrm{E}\right)$ in Odeda Local Government Area of Ogun State, South Western Nigeria (Fig. 1) during the 2017 and 2018 cropping seasons. The study area is characterized by a tropical climate with distinct wet and dry seasons with bimodal rainfall pattern and mean annual air temperature of about $30^{\circ} \mathrm{C}$. The actual rainfall totals during the 2017 and 2018 cropping season were 1177.2 and $1201.6 \mathrm{~mm}$, respectively. The mean annual air temperature during the experimental years is $30^{\circ} \mathrm{C}$. The soil at the experimental site was categorized as a well-drained tropical ferruginous soil. The A horizon of the soil is an Oxic Paleudulf of the Iwo series with $83 \%$ sand, $5 \%$ silt and $12 \%$ clay with a pH 6 considered tolerable for yam cultivation (Olasan$\tan , 2007)$.

\section{Experimental design and field measurement}

A 3 years (from 2014-2016) fallowed piece of land was prepared as experimental site before the study 


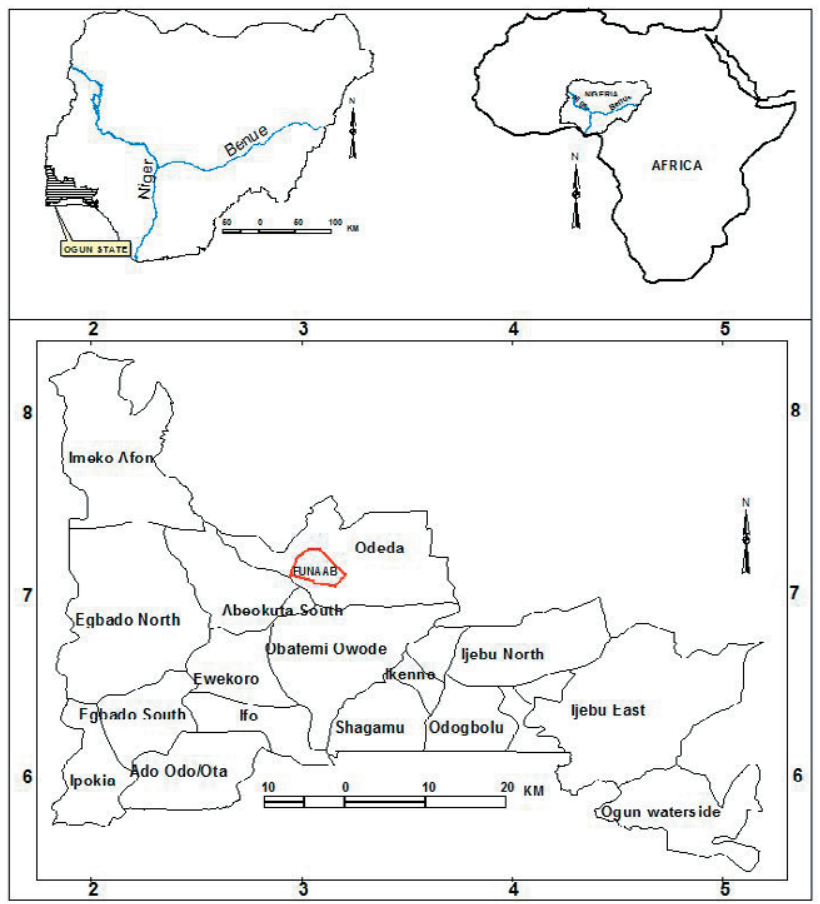

Fig. 1. Location of University of Agriculture, Abeokuta within Odeda Local Government Area in Ogun State, Southwestern Nigeria, Africa.

began. The site was cleared manually using cutlass in November 2016, in preparation for the 2016-2017 cropping following the popular practice by the farmers in the study area. This period marks the preparatory period for the cultivation of early yam planting in the study area. Yam mounds of height $60 \mathrm{~cm}$ and spaced $1.5 \mathrm{~m} \mathrm{x} 1.5$ $\mathrm{m}$ a walk way of $1 \mathrm{~m}$ between adjacent rows were made manually using African hoe to improve the soil aeration and hydrothermal conditions for crops emergence, root development, crop growth and yield (Kutugi, 2002). Three most important edible local white yam, Dioscorea rotundata cultivars (Efuru, ' $\mathrm{A}_{1}$; Ise-osi ' $\mathrm{A}_{2}$; and Oniyere $' \mathrm{~A}_{3}$ ) were used. During each of the phenological stages, daily observation of air temperature $\left({ }^{\circ} \mathrm{C}\right)$, wind speed at

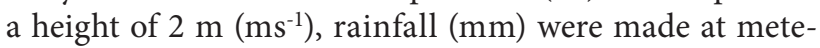
orological enclosure adjacent to the experimental field. Other climatic parameters measured were open water evaporation $\left(E_{O}\right)$ in $\mathrm{mm}$ determined according to Penman-Monteithformula using CROPWAT, 2009 model, actual water availability (AWA, $\mathrm{mm}$ ) and consumptive water used by the crop $\left(\mathrm{ET}_{\text {crop }}\right.$ or water requirement 'WR) in mm was computed as follow:

$\mathrm{ET}_{\text {crop }}=\mathrm{K}_{\mathrm{C}} \times \mathrm{E}_{\mathrm{O}} \mathrm{mm}$

where $\mathrm{K}_{\mathrm{C}}=$ Crop coefficient
$\mathrm{K}_{\mathrm{C}}$ otherwise referred to as the relative evaporation is expressed as ET. $\mathrm{E}_{\mathrm{O}}{ }^{-1}$, where $\mathrm{ET}$ and $\mathrm{E}_{\mathrm{O}}$ were measured parameters. The crop coefficients $(\mathrm{Kc})$ values, represent the crop type and the development of the crop. The Kc values for this study were adopted from FAO (1977) for crops. AWA according FAO (1977) was taken as the difference between actual precipitation and crop water requirement,

$\mathrm{AWA}=\mathrm{P}^{-\mathrm{ET}_{\text {crop }}}$

AWA is equivalent to available rainfall (P) plus change in stored water and this in turn correspond to actual evaporation. Therefore, for periods when $\mathrm{P}$ is less than potential Evapotranspiration $(\mathrm{PE}) \mathrm{AWA}=\mathrm{ET}_{\text {crop }}$ but for periods where $\mathrm{P}$ is greater than $\mathrm{ET}_{\text {crop, }} \mathrm{AWA}=$ $\mathrm{P}$, since in this case actual Evapotranspiration (AE) = $\mathrm{ET}_{\text {crop }}$ while there is virtually no depletion of soil moisture. The quotient of AWA and $\mathrm{ET}_{\text {crop }}$ or $\mathrm{WR}$ enable a determination of the degree of humidity which is tolerable by a cultivated plant during the growing season, and allow sub-division to be applied between arid and humid environments. Deichmann and Eklundh (1991) set an aridity limit at 1.0 and a critical humidity limit at 2.0. Therefore the moisture supply for yam in this study was regarded as supra- optimum for an AWA:WR ratio above 2.0, optimum for a ratio between 1.0 and 2.0 and deficient for a ratio below 1.0. Climatic parameters were not measured directly at the experimental site but were estimated using meteorological tables (Doorenbos and Pruitt, 1984).

Furthermore, the rainfall-potential evapotranspiration ( $\mathrm{P}$ and $\mathrm{PE}$ ) model according to the procedure of Cocheme and Franquin, (1967) were followed to determine start and end of planting. The model used in this study was formulated to incorporate farmer's conventional calendar for yam cultivation. Consequently, planting date $(\mathrm{T})$ was selected based on the following general model

\section{$0.1 \mathrm{PE}<\mathrm{P}<0.5 \mathrm{PE}$}

The time of planting is taken as the as period when accumulated difference between rainfall $\mathrm{P}$ and one tenth $\mathrm{PE}$ is zero $\left(\sum(\mathrm{P}-0.1 \mathrm{PE}) \leq 0\right)$. It follows that the two specific planting dates $\left(T_{1} \& T_{2}\right)$ in each experimental years were generated from the general model above as follows:

$\mathrm{T}_{1}=\sum(\mathrm{P}-0.1 \mathrm{PE}) \leq 24=$ March 22 which fell in the $9^{\text {th }}$ decade of 2017

$\mathrm{T}_{2}=\sum(\mathrm{P}-0.1 \mathrm{PE}) \leq 259=$ June 5 which fell in the $16^{\text {th }}$ decade of 2017 
$\mathrm{T}_{1}=\sum(\mathrm{P}-0.1 \mathrm{PE}) \leq 10=$ January 21 which fell in the $3^{\text {rd }}$ decade of 2018

$\mathrm{T}_{2}=\sum(\mathrm{P}-0.1 \mathrm{PE}) \leq 182=$ April 6 which fell in the $10^{\text {th }}$ decade of 2018

And the conventional farmer's planting date adopted from Ogun state Agricultural Development Program (OGADEP) records as follows:

$\mathrm{F}_{1}=\sum(\mathrm{P}-0.1 \mathrm{PE}) \leq 0=$ January 7 which fell in the $1^{\text {st }}$ decade of 2017 and 2018

$\mathrm{F}_{2}=\sum(\mathrm{P}-0.1 \mathrm{PE}) \leq 150=$ April 15 which fell in the $10^{\text {th }}$ decade of 2017 and 2018

The planting dates for the two cropping seasons (2017 and 2018 respectively) are as presented. The yam cultivar were cut into yam setts weighing an average of $550 \mathrm{~g}$ and planted at a depth of $15 \mathrm{~cm}$ on mounds. After sprouting, the yams were staked to about $3 \mathrm{~m}$ high and the vines were trained regularly. No fertilizer and insecticide were applied and all plots were regularly hand weeded. Bush rat was controlled by regular clearing of the surroundings of the project site. The climatic requirements of yam from planting to harvesting were measured according to developmental stages of yam growth cycle form the time scale for which the collected data have been processed.The leaf area was calculated from leaf area of plant multiplied by total number of plant. While the leaf area index (LAI) according to Hunt (1978) formula is given as

$\mathrm{LAI}=\frac{\text { Leaf area }}{\text { Land area }}=$

Total area / plot x No.of leaves / plot x No.of stand / plot x \% emergence /plot Land area / plot

\section{Method of soil moisture conservation}

Grass mulch $\left(\mathrm{M}_{1}\right)$ of $40 \mathrm{~cm}$ diameter, and $70 \mathrm{~cm} \mathrm{x}$ $50 \mathrm{~cm}$ perforated polythene nylon mulch $\left(\mathrm{M}_{2}\right)$ with side covering the mound as black surface and white surface facing the atmosphere wereused for evaporation suppression. Mulching was done after planting between 6.307.30 in the morning and removed from the mound at humid period $\left[\left(\sum(\mathrm{P}-0.1 \mathrm{PE})=0\right]\right.$ experienced at $25^{\text {th }}$ July (21 decade) for 2017 experimental year and $25^{\text {th }}$ June (18 ${ }^{\text {th }}$ decade) for 2018 experimental year.In addition to the mulched plot, un-mulch treatment was included in the experiment which served as control (C). This period coincided with the early tuber formation stage of yam. This period is the time when most traditional farmers in West Africa normally remove mulch materials. According to his work, it revealed that if the mulch materials are not removed during the tuber formation stage, it will prevent the infiltration of rainwater to encourage good tuberization.

Apart from the daily observation of meteorological parameters measured and estimated during the phenological stages, phenological crop growth parameter and yield characters were also measured. Data collected were subjected to analysis of variance (ANOVA) using Genstat statistical package discovery edition 3 to evaluate the effects of variety, planting date (season) and "mulching and mulching materials" on the growth and yield of white yam. The significant difference of treatment means were determined using least significance difference (LSD) 5\% level of probability. The result of yield from experiment using model planting date $\left(\mathrm{T}_{1} \& \mathrm{~T}_{2}\right)$ and the yield obtained from Ogun State Ministry of Agriculture and Ogun state Agricultural Development Program [Farmer's conventional planting period $\left(\mathrm{F}_{1} \& \mathrm{~F}_{2}\right)$ ]were compared to ascertain the effectiveness of model.

\section{RESULTS AND DISCUSSION}

The relationship between AWA and WR during the phenological stages, presented in figures 2 and 3 shows that though annual total water supply was adequate for the growth of yam for both experimental years, a long term moisture stress (AWA: WR $<1$ ) resulting from short fall in AWA encountered before the onset of rainfall, perticularly during the emergence period was pronounced for the 2017 experimental year. This was noticed to cause loss of setts and disparity in emergence which led to growth retardation and reduction in tuber yield. The moisture stress was badly felt by most farmers in the area that depended solely on the yam calendar for planting (F1). However, the P-PE model prediction of planting date $\mathrm{T} 1$ ( $^{\text {th }}$ decade) was able to reduce this problem to a bearable level. Furthermore, excessive moisture which appeared to be supra optimal (AWA: $\mathrm{WR}>2$ ) was experienced during the moisture critical stages of late vegetative growth, the tuber initiation and tuber bulking period in the 2017 experimental year. This could be attributed to part of high AWA which occurred during the period when $\mathrm{P}$ was consistently greater than PE. The high AWA experienced at this period could also cause leaching of plant nutrient which reduced harvested tuber yield (Bello, 2000). It was also observed that earlier planting $\left\{\mathrm{T}_{1}=\left(\sum(\mathrm{P}-0.1 \mathrm{PE}) \leq 24\right.\right.$ which marked the $9^{\text {th }}$ decade of 2017 and $\mathrm{T}_{1}=\left(\sum(\mathrm{P}-0.1 \mathrm{PE}) \leq 10\right.$ which marked with $3^{\text {rd }}$ decade of 2018$\}$ so that the entire phenological stages coincided with period of AWA led to relatively longer period of complete plot emergence and the vege- 


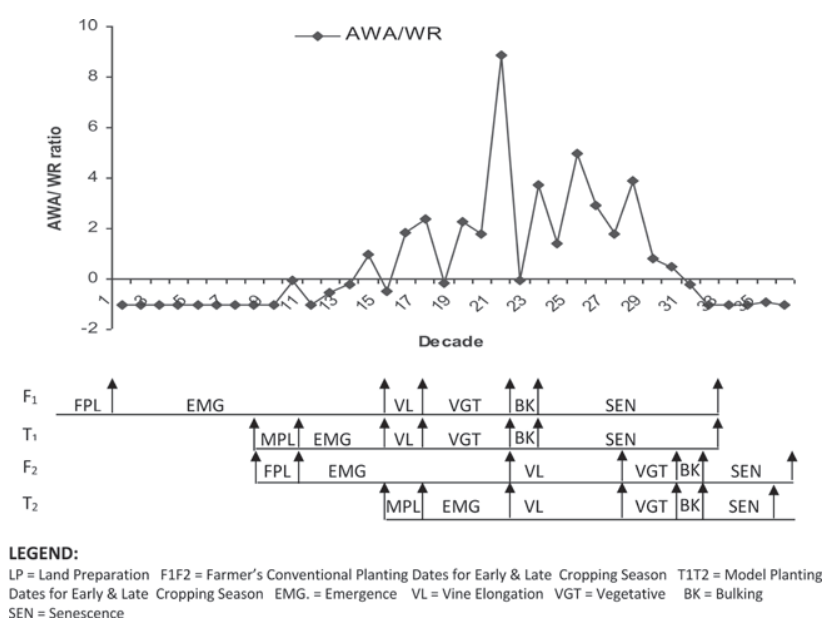

Fig. 2. Ratio between AWA and crop's water requirement (WR) for the two planting dates and conventional planting data at yam phenological stages in Abeokuta in 2017.

tative growth and consequently higher final yield whereas, late planting $\left\{\mathrm{T}_{2}=\left(\sum(\mathrm{P}-0.1 \mathrm{PE}) \leq 259\right.\right.$ which marked the $16^{\text {th }}$ decade of 2017 and $\mathrm{T}_{2}=\left(\sum(\mathrm{P}-0.1 \mathrm{PE}) \leq 182\right.$ which marked the $10^{\text {th }}$ decade of 2018 led to a situation whereby the AWA was not able to satisfy the moisture requirement of crop at the critical moisture requirement period of bulking before the cessation of rains which could lead to delay tuber initiation in yams and consequently causing considerably low tuber size and yam yield, this agreed with Maikasuwa and Ala (2013).

According to Odjugo (2008), the most critical stages for water requirement for yam are the tuber initiation and bulking. However, yam still requires water throughout its active growth period for vine and leaf development. It was not surprising to see that early planting designated $\mathrm{T}_{1}$ [i.e $\Sigma(\mathrm{P}-0.1 \mathrm{PE}) \leq 24$ ] in 2017 characterized unpredictable distribution of rainfall significantly influencing emergence rate, vine length, number of leaves, number of branches, number of roots, root length, LAI, tuber length, tuber diameter, tuber weight, number of tuber and harvest yield (Tables 1 and 2). The variability of rainfall, characterized by late onset of rainfall (i.e. the accumulated difference between $\mathrm{P}$ and $0.5 \mathrm{PE}$ was very high), prolonged dry spell after planting during sprouting and emergence period and unbroken succession of wet days during the critical water requirement stage of bulking resulted in low growth and yield. Whereas, in the 2018 experimental year early planting was characterized by low accumulated difference between $\mathrm{P}$ and 0.5PE gave no significant difference $(\mathrm{P}>0.05)$ between early planting $T_{1}$ and late planting $T_{2}$ on the emergence rate, vine length, number of branches, number of roots, vine diameter, root length, branch length, tuber length,

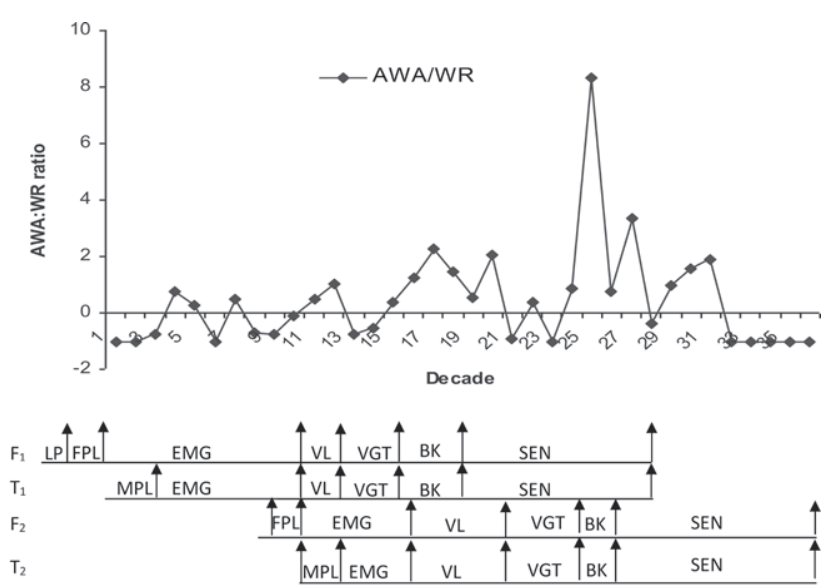

LEGEND:

$L P=$ Land Preparation $F 1 F 2=$ Farmer's Conventional Planting Dates for Early \& Late Cropping Season $T 1 T 2=$ Model Planting Dates for Early \& Late Cropping Season EMG. = Emergence $V L=$ Vine Elongation VGT = Model Planting Dates for Early \& Late Cropping
Vegetative $\mathrm{BK}=$ Bulking $\quad \mathrm{SEN}=$ Senescence

Fig. 3. Ratio between AWA and crop's water requirement (WR) for the two planting dates and conventional planting data at yam phenological stages in Abeokuta in 2018.

tuber diameter, tuber weight, number of tuber and harvest yield (Table 3 and 4). However, for the 2018 experimental year, the P-PE model date of early planting $\mathrm{T}_{1}$ had significantly influenced number of leaves and LAI. The higher leave area and LAI during the early season can be attributed to the adequate moisture availability. The high LAI was due to high leaves production and retention of leaves during the early planting than the late planting. The amount of leaf area available during tuber bulking period largely determines tuber yield in yam. Generally, the early planting particularly when the value of accumulated difference between $\mathrm{P}$ and $0.5 \mathrm{PE}$ were low as in 2018 cropping season was observed to have more yield when compared to early planting of 2017 cropping season that had high accumulated difference between $\mathrm{P}$ and 0.5PE. Furthermore, the early planting $\mathrm{T}_{1}$ was observed to have more yield than late planting $\mathrm{T}_{2}$ in both experimental years. The high yield from the early planting than the late planting for both experimental years related to the higher LAI which ensures higher bulking rate for a longer period and can also be attributed to phosphorus and mineralized nitrogen which are naturally high during the early rains absorbed by yams during growth (Zaknayiba and Tanko, 2013). While the significant low yield arising from delayed planting until the $9^{\text {th }}$ decade of 2017 experimental year using model and even lower yield when farmer's conventional method (yield data collected from OGADEP) was used as shown in Figures 4 and 5 indicated that natural nutrient were largely missing as a result of leaching.This is moreso that the accumulated difference between $\mathrm{P}$ and $0.1 \mathrm{PE}$ at the 
Table 1. Effect of variety, planting dateand mulching and mulching materials on growth of yamduring 2017 cropping season.

\begin{tabular}{|c|c|c|c|c|c|c|c|c|c|}
\hline Factor & $\begin{array}{c}\text { Emergence } \\
(\%)\end{array}$ & $\begin{array}{l}\text { Vine } \\
\text { elongation } \\
(\mathrm{cm})\end{array}$ & $\begin{array}{c}\text { No. of } \\
\text { branches }\end{array}$ & No. of leaves & No of roots & $\begin{array}{c}\text { Vine } \\
\text { diameter } \\
(\mathrm{cm})\end{array}$ & $\begin{array}{l}\text { Branch } \\
\text { length } \\
(\mathrm{cm})\end{array}$ & $\begin{array}{l}\text { Root length } \\
\quad(\mathrm{cm})\end{array}$ & LAI \\
\hline \multicolumn{10}{|l|}{ Yam varieties } \\
\hline Efuru $A_{1}$ & $41.7 \pm 7.21$ & $83.9 \pm 26.20$ & $20.8 \pm 2.42$ & $499.5 \pm 121.14$ & $21.1 \pm 2.96$ & $1.511 \pm 0.07$ & $71.8 \pm 7.76$ & $31.1 \pm 3.12$ & $1.078 \pm 0.42$ \\
\hline Ise-osi $\mathrm{A}_{2}$ & $44.0 \pm 6.45$ & $74.4 \pm 24.69$ & $15.5 \pm 2.40$ & $571.8 \pm 129.32$ & $21.4 \pm 2.28$ & $1.358 \pm 0.07$ & $65.3 \pm 6.02$ & $29.1 \pm 2.61$ & $0.911 \pm 0.28$ \\
\hline Oniyere $\mathrm{A}_{3}$ & $43.8 \pm 6.93$ & $70.8 \pm 23.83$ & $19.2 \pm 2.61$ & $380.7 \pm 72.89$ & $18.3 \pm 2.63$ & $1.294 \pm 0.04$ & $55.3 \pm 6.29$ & $25.7 \pm 2.93$ & $0.439 \pm 0.12$ \\
\hline Prob. Level P & 0.838 & 0.805 & 0.253 & $<0.001^{\star}$ & 0.637 & $0.026^{\star *}$ & 0.186 & 0.411 & $0.002^{\star}$ \\
\hline \multicolumn{10}{|l|}{ Planting season } \\
\hline $\mathrm{T}_{1}$ & $54.6 \pm 5.57$ & $137.6 \pm 22.9$ & $21.8 \pm 2.04$ & $776.3 \pm 98.74$ & $24.3 \pm 2.33$ & $1.424 \pm 0.06$ & $68.7 \pm 5.66$ & $32.8 \pm 2.58$ & $1.396 \pm 0.32$ \\
\hline $\mathrm{T}_{2}$ & $31.7 \pm 4.83$ & $15.3 \pm 4.38$ & $15.2 \pm 1.92$ & $191.6 \pm 29.76$ & $16.2 \pm 1.67$ & $1.352 \pm 0.05$ & $59.6 \pm 5.60$ & $24.5 \pm 1.94$ & $0.141 \pm 0.04$ \\
\hline Prob. Level P & $<0.001^{\star}$ & $<0.001^{\star}$ & $0.017^{\star *}$ & $<0.001^{\star}$ & $0.009^{*}$ & 0.266 & 0.217 & $0.016^{* *}$ & $<0.001^{\star}$ \\
\hline \multicolumn{10}{|l|}{ Mulching material } \\
\hline UnmulchC & $14.8 \pm 2.71$ & $31.1 \pm 15.54$ & $14.3 \pm 1.41$ & $239.6 \pm 42.56$ & $20.2 \pm 2.90$ & $1.272 \pm 0.08$ & $58.8 \pm 6.82$ & $23.8 \pm 3.15$ & $0.044 \pm 0.02$ \\
\hline Grass mulch $\mathrm{M}_{1}$ & $68.4 \pm 5.33$ & $150.4 \pm 30.21$ & $24.3 \pm 2.98$ & $757.2 \pm 125.68$ & $23.7 \pm 2.97$ & $1.447 \pm 0.05$ & $74.9 \pm 6.34$ & $32.2 \pm 2.84$ & $1.650 \pm 0.42$ \\
\hline Nylon mulch $\mathrm{M}_{2}$ & $46.2 \pm 5.20$ & $47.7 \pm 16.22$ & $16.9 \pm 2.43$ & $455.2 \pm 117.99$ & $16.9 \pm 1.80$ & $1.444 \pm 0.05$ & $58.7 \pm 7.21$ & $28.9 \pm 2.53$ & $0.611 \pm 0.21$ \\
\hline Prob. Level P & $<0.001^{\star}$ & $<0.001^{\star}$ & $0.010^{\star}$ & $<0.001^{\star}$ & 0.190 & $0.049^{\star *}$ & 0.124 & 0.079 & $<0.001^{\star}$ \\
\hline
\end{tabular}

${ }^{\star}$ Significant at $\mathrm{P}<0.01$. ${ }^{*}$ Significant at $\mathrm{P}<0.05$.

Table 2. Effect of variety, planting dateand mulching and mulching materials on yield and yield characteristic of yamduring 2017 cropping season.

\begin{tabular}{|c|c|c|c|c|c|}
\hline Factor & $\begin{array}{l}\text { Tuber length } \\
(\mathrm{cm})\end{array}$ & $\begin{array}{l}\text { Tuber diameter } \\
\qquad(\mathrm{cm})\end{array}$ & $\begin{array}{c}\text { Tuber weight } \\
(\mathrm{kg})\end{array}$ & No of tuber & $\begin{array}{l}\text { Harvest yield } \\
\text { (ton/ha) }\end{array}$ \\
\hline \multicolumn{6}{|l|}{ Variety } \\
\hline Efuru & $17.0 \pm 3.81$ & $4.89 \pm 1.05$ & $1.67 \pm 0.37$ & $0.778 \pm 0.24$ & $5.38 \pm 1.47$ \\
\hline Ise-osi & $23.3 \pm 3.87$ & $6.03 \pm 0.98$ & $1.56 \pm 0.31$ & $0.750 \pm 0.12$ & $4.97 \pm 1.03$ \\
\hline Oniyere & $18.8 \pm 4.18$ & $5.41 \pm 1.21$ & $1.54 \pm 0.36$ & $0.556 \pm 0.12$ & $4.54 \pm 1.39$ \\
\hline 0.235 & 0.502 & 0.891 & 0.378 & 0.214 & \\
\hline \multicolumn{6}{|l|}{ Planting date } \\
\hline $\mathrm{T} 1$ & $30.0 \pm 2.73$ & $8.30 \pm 0.73$ & $2.60 \pm 0.25$ & $1.019 \pm 0.13$ & $8.04 \pm 1.17$ \\
\hline $\mathrm{T} 2$ & $9.4 \pm 2.48$ & $2.59 \pm 0.67$ & $0.58 \pm 0.16$ & $0.370 \pm 0.95$ & $1.42 \pm 0.41$ \\
\hline Prob. Level P & $<0.001^{*}$ & $<0.001^{\star}$ & $<0.001^{\star}$ & $<0.001^{*}$ & $<0.001^{\star}$ \\
\hline \multicolumn{6}{|l|}{ Mulch material } \\
\hline Unmulch C & $10.60 \pm 3.91$ & $2.89 \pm 1.01$ & $0.84 \pm 0.29$ & $0.556 \pm 0.23$ & $1.11 \pm 0.41$ \\
\hline Grass mulch M1 & $27.7 \pm 2.19$ & $8.30 \pm 0.70$ & $2.37 \pm 0.30$ & $0.972 \pm 0.06$ & $8.74 \pm 1.50$ \\
\hline Nylon mulch M2 & $20.8 \pm 4.58$ & $5.14 \pm 1.45$ & $1.56 \pm 0.38$ & $0.556 \pm 0.12$ & $4.35 \pm 1.14$ \\
\hline Prob. Level P & $<0.001^{\star}$ & $<0.001^{\star}$ & $<0.001^{\star}$ & $<0.028^{\star *}$ & $<0.001^{\star}$ \\
\hline
\end{tabular}

${ }^{\star}$ Significant at $\mathrm{P}<0.01 .{ }^{* *}$ Significant at $\mathrm{P}<0.05$.

$9^{\text {th }}$ decade of 2017 had become significantly high (14$28 \mathrm{~mm}$ ). The period was observed to extend to the late planting at $16^{\text {th }}$ decade. It is noteworthy that in the case of late onset of rains, farmers may become apprehensive of a planting date that fails to ensure that the crop matures by the end of the rains. Consequently, they may tend to plant immediately after the value of accumulated difference between $\mathrm{P}$ and 0.5PE approaches zero in other to avoid possible incidence of drought at critical moisture period of bulking.

It follows in the same vein that significant declined in yield occurred when accumulated difference between $\mathrm{P}$ and $0.1 \mathrm{PE}$ was in excess of $10 \mathrm{~mm}$. Thus planting can be done when accumulated difference between $\mathrm{P}$ and 
Table 3. Effect of variety, planting dateand mulching and mulching materials on growth of yamduring 2018 cropping season.

\begin{tabular}{|c|c|c|c|c|c|c|c|c|c|}
\hline Factor & $\begin{array}{c}\text { Emergence } \\
(\%)\end{array}$ & $\begin{array}{l}\text { Vine } \\
\text { elongation } \\
(\mathrm{cm})\end{array}$ & $\begin{array}{c}\text { No. of } \\
\text { branches }\end{array}$ & No. of leaves & No of roots & $\begin{array}{c}\text { Vine } \\
\text { diameter } \\
(\mathrm{cm})\end{array}$ & $\begin{array}{l}\text { Branch } \\
\text { length } \\
(\mathrm{cm})\end{array}$ & $\begin{array}{l}\text { Root length } \\
\qquad(\mathrm{cm})\end{array}$ & LAI \\
\hline \multicolumn{10}{|l|}{ Yam varieties } \\
\hline Efuru & A172.2 \pm 6.66 & $462 \pm 56.75$ & $22.2 \pm 3.17$ & $439.9 \pm 46.6$ & $25.8 \pm 3.19$ & $1.528 \pm 0.07$ & $83.2 \pm 13.23$ & $32.3 \pm 2.92$ & $1.035 \pm 0.21$ \\
\hline Ise-osi $\mathrm{A}_{2}$ & $71.3 \pm 4.78$ & $326 \pm 32.82$ & $21.4 \pm 3.58$ & $484 \pm 85.05$ & $26.8 \pm 3.08$ & $1.369 \pm 0.08$ & $72.8 \pm 7.60$ & $31.1 \pm 2.36$ & $0.917 \pm 0.24$ \\
\hline Oniyere $\mathrm{A}_{3}$ & $70.3 \pm 4.97$ & $319 \pm 26.59$ & $23.2 \pm 3.69$ & $435.2 \pm 46.67$ & $23.7 \pm 3.34$ & $1.322 \pm 0.05$ & $79.0 \pm 7.64$ & $32.2 \pm 3.46$ & $0.823 \pm 0.14$ \\
\hline Prob. Level P & 0.935 & $<0.001^{\star}$ & 0.927 & $<0.001^{\star}$ & 0.808 & 0.059 & 0.746 & 0.956 & 0.061 \\
\hline \multicolumn{10}{|l|}{ Planting date } \\
\hline $\mathrm{T}_{1}$ & $74.0 \pm 4.13$ & $381 \pm 40.29$ & $25.1 \pm 2.97$ & $568.1 \pm 57.22$ & $29.4 \pm 2.82$ & $1.465 \pm 0.05$ & $94 \pm 9.13$ & $35.5 \pm 2.60$ & $1.230 \pm 0.17$ \\
\hline $\mathrm{T}_{2}$ & $68.5 \pm 4.6$ & $357 \pm 28.03$ & $19.4 \pm 2.58$ & $332.6 \pm 28.65$ & $21.5 \pm 2.19$ & $1.348 \pm 0.06$ & $62.7 \pm 5.92$ & $28.2 \pm 2.02$ & $0.628 \pm 0.10$ \\
\hline Prob. Level P & 0.205 & 0.424 & 0.121 & $<0.001^{\star}$ & $0.05^{\star \star}$ & 0.109 & $0.008^{\star}$ & $0.044^{\star *}$ & $<0.001^{\star}$ \\
\hline \multicolumn{10}{|l|}{ Mulching material } \\
\hline UnmulchC & $51.6 \pm 3.81$ & $271 \pm 34.29$ & $12.6 \pm 1.13$ & $255.0 \pm 16.7$ & $23.8 \pm 4.22$ & $1.261 \pm 0.07$ & $68.1 \pm 7.09$ & $28.9 \pm 3.22$ & $0.339 \pm 0.06$ \\
\hline Grass mulch $\mathrm{M}_{1}$ & $94.0 \pm 1.56$ & $476 \pm 37.0$ & $32.4 \pm 3.72$ & $680.3 \pm 65.80$ & $27.8 \pm 3.13$ & $1.508 \pm 0.06$ & $101.1 \pm 12.67$ & $34.7 \pm 2.73$ & $1.706 \pm 0.17$ \\
\hline Nylon mulch $\mathrm{M}_{2}$ & $68.1 \pm 4.30$ & $360 \pm 41.91$ & $21.7 \pm 3.20$ & $415.8 \pm 42.49$ & $24.8 \pm 1.98$ & $1.450 \pm 0.06$ & $65.9 \pm 7.60$ & $32.0 \pm 2.87$ & $0.751 \pm 0.10$ \\
\hline Prob. Level P & $<0.001^{\star}$ & $<0.001^{\star}$ & $<0.01^{\star}$ & $<0.001^{\star}$ & 0.700 & $0.019^{* *}$ & $0.023^{\star *}$ & 0.408 & $<0.001^{\star *}$ \\
\hline
\end{tabular}

${ }^{\star}$ Significant at $\mathrm{P}<0.01 .{ }^{*}$ Significant at $\mathrm{P}<0.05$

Table 4. Effect of variety, planting dateand mulching and mulching materials on yield and yield characteristic of yam during the 2018 cropping season.

\begin{tabular}{|c|c|c|c|c|c|}
\hline Factor & $\begin{array}{l}\text { Tuber length } \\
\qquad(\mathrm{cm})\end{array}$ & $\begin{array}{l}\text { Tuber diameter } \\
\qquad(\mathrm{cm})\end{array}$ & $\begin{array}{l}\text { Tuber weight } \\
(\mathrm{kg})\end{array}$ & No of tuber & $\begin{array}{l}\text { Harvest yield } \\
\text { (ton/ha) }\end{array}$ \\
\hline \multicolumn{6}{|l|}{ Yam variety } \\
\hline Efuru & $34 \pm 2.63$ & $10.09 \pm 0.76$ & $3.33 \pm 0.34$ & $1.056 \pm 0.07$ & $11.94 \pm 1.71$ \\
\hline Ise-osi & $34.2 \pm 1.91$ & $12.05 \pm 0.54$ & $3.36 \pm 0.22$ & $1.139 \pm 0.04$ & $11.64 \pm 1.18$ \\
\hline Oniyere & $40.3 \pm 2.00$ & $11.81 \pm 0.59$ & $3.33 \pm 0.25$ & $1.178 \pm 0.04$ & $11.53 \pm 1.40$ \\
\hline Prob. Level P & 0.066 & $0.028^{\star \star}$ & 0.993 & 0.567 & 0.936 \\
\hline \multicolumn{6}{|l|}{ Planting date } \\
\hline $\mathrm{T} 137.7 \pm 2.13$ & $11.49 \pm 0.644$ & $3.55 \pm 0.24$ & $1.133 \pm 0.06$ & $12.70 \pm 1.16$ & \\
\hline $\mathrm{T} 2$ & $34.7 \pm 1.56$ & $11.14 \pm 0.43$ & $3.13 \pm 0.18$ & $1.115 \pm 0.03$ & $10.71 \pm 1.14$ \\
\hline Prob. Level P & 0.223 & 0.575 & 0.098 & 0.764 & $0.043^{\star *}$ \\
\hline \multicolumn{6}{|l|}{ Mulch material } \\
\hline Unmulch C & $31.8 \pm 2.87$ & $9.52 \pm 0.75$ & $2.54 \pm 0.29$ & $1.078 \pm 0.08$ & $6.24 \pm 0.87$ \\
\hline Grass mulch M1 & $39.1 \pm 1.71$ & $12.36 \pm 0.53$ & $3.97 \pm 0.17$ & $1.150 \pm 0.03$ & $17.59 \pm 0.88$ \\
\hline Nylon mulch M2 & $37.6 \pm 1.87$ & $12.08 \pm 0.50$ & $3.52 \pm 0.21$ & $1.144 \pm 0.04$ & $11.28 \pm 0.94$ \\
\hline Prob. Level P & $0.043^{* *}$ & $<0.001^{\star}$ & $<0.001^{\star}$ & 0.567 & $<0.001^{\star}$ \\
\hline
\end{tabular}

${ }^{*}$ Significant at $\mathrm{P}<0.01 .{ }^{*}$ Significant at $\mathrm{P}<0.05$.

$0.1 \mathrm{PE}$ is less than $10 \mathrm{~mm}$ (i.e $\Sigma(\mathrm{P}-0.1 \mathrm{PE}) \leq 10 \mathrm{~mm}$ ). The implication for the schedule of farm operations for yam cultivation in the area is that land preparation should commence as soon as the accumulated difference between $\mathrm{P}$ and $0.1 \mathrm{PE}$ approaches zero while mound construction and planting could be done simultaneously immediately the difference reaches the zero value. Under no circumstance must farmer delay planting until the accumulated difference exceed $10 \mathrm{~mm}$. This schedule is to ensure that adverse effects of high AWA are avoided or minimized while, at the same time, precautions are taken against possible shortfall in the duration of the rains, particularly if such an early onset of the rains is flawed by an abnormal early or sudden cession. In a situ- 


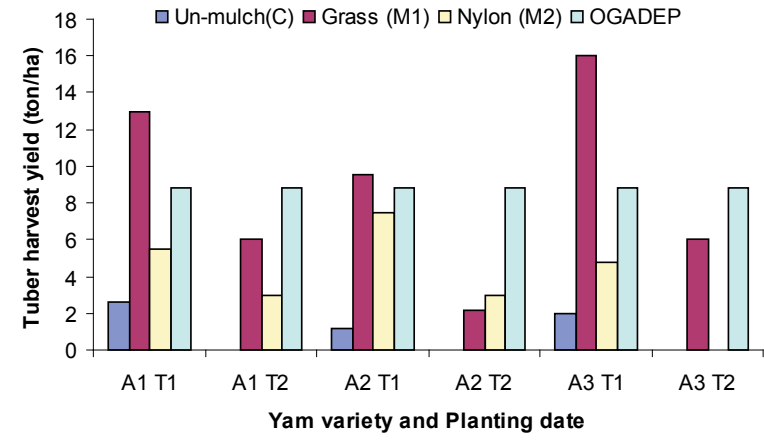

Fig. 4. Effect of planting date, mulching and mulching materials and varietyon tuber yield of three white yam grown at Abeokuta in 2017.

ation where the onset of the rains is extremely late such that incidence of drought is imminent and the duration of the rains might possibly fall short of 240days (24dacades- growing days of yam), then variety with phenology that synchronize perfectly with the pattern of AWA should be selected.

The importance of mulching in yam cultivation cannot be overemphasized particularly in the study area (Western Nigeria) where severe moisture deficit had been known to cause loss of setts and disparity in emergence. The water deficit is also known to reduce growth and tuber yield which normally contributed to economic loss. The study showed that mulching altered the microclimate favourably and resulted in improved yam growth, development and tuber yield in the study area as observed in the effect of mulching and mulching materials on the phenological crop growth of yam which was noticed to similar in both experimental years Tables 1 and 3. Generally, the yams planted under mulched plot were significantly higher in emergence rate, vine length, number of stem branches, and number of leaves and LAI of yam than for un-mulched plot. It was also found that mulching increased tuber yield by about 6-8 tha${ }^{1}$ than the unmulched. This finding agreed with previous report that the emergence and growth rate of yam seedling were observed to be significantly higher in mulched plots than the un-mulched plot by Olasantan 1999 and Odjugo,2008. Increased emergence and more rapid development of setts in mulched yams could be attributed to an increase in soil moisture content and the consequent modification of soil temperature under mulched plot (Okoh, 2004; Iyang, 2005). Furthermore, there was significant difference in these parameters with different type of mulching material used for the two experimental year. The grass mulched significantly improved the growth, development and yield of yam than the perforated white surface up and black surface facing down

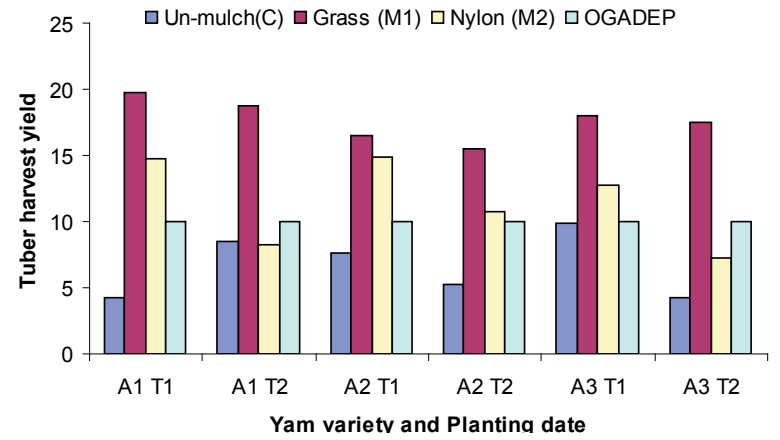

Fig. 5. Effect of planting date, mulching and mulching materials and varietyon tuber yield of three white yam grown at Abeokuta in 2018 .

polythene nylon.Grass mulch had tuber yield of about 4-6 tha ${ }^{-1}$ greater than the polythene mulch and the unmulched plots. The beneficial effects of grass mulch on yam growth could be attributed to the nutrients released by decomposing mulch (Olasantan, 1999), and its physical effect on the possible reduction of nutrient losses by surface erosion and leaching. Furthermore, the beneficial effect of polythene nylon was also discussed by Odjugo, (2008). It is interesting to note that there were no significant difference between number of roots, vine diameter and root length of yam planted under mulched and unmulched plot, and also with different type of mulching material used during the two experimental year.

The effect of mulching and mulching material on the yield and yield components of yam were also similar in both experimental years. Generally, irrespective of planting date and variety of white yam planted, the yam planted under mulched plot were significantly higher in tuber length, tuber diameter, tuber weight and yield of yam than for un-mulched plot. This finding also agreed with previous report that the yield and yield components of yam were observed to be significantly higher in mulched plots than the un-mulched plot by Anthony and Ben, 2018. However, the significant reduction in the tuber length, tuber diameter, tuber weight and yield of yam as experienced in the 2017 experimental year as compared to 2018 year could be attributed to the moisture stress that marked the arid period of the 2017 year as earlier mentioned above thereby causing disparity in yam setts sprouting in all varieties under all mulched and un-mulched plots. Furthermore, there was significant difference in these parameters with different type of mulching material used for the two experimental years. The grass mulched plots were observed to be significantly higher than the perforated white surface up and black surface facing down polythene nylon. The beneficial effects of mulch on tuber yield particularly during 
the 2018 experimental year were probably due to favourable hydrothermal regimes of the soil for emergence and early development of yam plants. The mulch was also observed to increase the growth and tuber yield of yams possibly by reducing nutrient losses through controlling runoff and leaching in the raining season. The high yield as experienced in the grass mulch was also attributed partly to the possible influence of decomposed mulch material on increase in soil nutrient status and availability since the grass mulch is known to contain some element of Nitrogen, magnesium, calcium, phosphorus and potassium (Hulugalle etal., 1986), and these nutrients, particularly $\mathrm{P}, \mathrm{N}$ and $\mathrm{K}$ are important in the growth and bulking of yam tubers, and consequently in the tuber yield (Hulugalle etal, 1986). Since fertilizer was not used in the study, the higher growth and tuber yield observed in the grass mulched plots compared to both the perforated white surface up and black surface facing down polythene nylon mulch and the un-mulched plots in the two experimental years was attributed to the effect of decomposed mulch on the nutrient content and in ameliorating soil physical conditions. It is also interesting to note that there was no significant difference between number of tuber of yam planted under mulched and unmulched plot and with different type of mulching material used during the two experimental year.

The selection of cultivar (variety) is among the factor that contributes to the realization of a successful cropping (Bello, 2000 and Olasntan, 2007). Hence, the study further confirmed the agro-climatic potential of the study area for three white yam varieties. The fact that the total rainfall (1177.2 and $1201.6 \mathrm{~mm}$ for 2017 and 2018 experimental years respectively) recorded at the study site fell within the range of optimum annual rainfall (1000-1500 $\mathrm{mm}$ ) reported for yam growth is not enough criteria for suitable crop variety selection in the study area. This was obvious in the high total rainfall received is as a result of one or two sporadic downpours, widely separated by periods of dry spells, experienced in the 2017 experimental year (Figure 2) which does not contribute meaningfully to the yam growth, rather, it the downpours generated flash floods while the little amount of rainfall evaporated rather than effectively recharging the soil for subsequent use by plant. It follows therefore that adequacy for good plant growth does not depend solely on total rainfall but a combination of rainfall and evaporation.

Since soil and thermal factors are not constraints though the duration of rains is appreciably longer and more reliable in Southwest than elsewhere in Nigeria. Selection of yam variety with appropriate phenologies that will synchronize the crop growth cycle with the period of effective water availability is required. For instance, it was observed from study that though there were no significant difference in most of the yam growth parameters measured like the emergence rate, vine length, number of stem branches, number of stem roots, branch length, tuber length, tuber diameter, tuber weight, number of tuber and the yield for the different yam variety planted during the 2017 and 2018 experiments, there were still some significant difference in some major parameter like the number of leaves, vine diameter and the LAI. It was observed that the Efuru and Ise-osi has the higher number of leaves and LAI followed by the Oniyere. Efuru and Ise-osi synchronized perfectly with the pattern of Actual Water Availability (AWA) and produced good vegetative growth with Leaf Area Index LAI, of 1.08 and 0.91 thereby leading to high tuber yield of 12 tonnes ha ${ }^{-1}$ and 11.64 tonnes ha-1, respectively. Oniyere had LAI of 0.44 resulting in a lower tuber yield of 11.53 tonnes $\mathrm{ha}^{-1}$.This implies that though all selected yam are suitable for planting in the study area. There are still some early maturing and moisture tolerant varieties that could have a larger canopy (LAI) and produce more yields even if the difference is little.

Generally, there was no significant interactive effect of planting date and mulching method, planting date and variety, mulching method and variety and planting date, mulching method and variety on growth parameters such as emergence rate, vine length, number of branches, number of roots, vine diameter, branch length and roots length (Tables 5 and 6) and also in yield and yield components (Tables 7 and 8) in both trials. However, there was an exceptional significant interaction $(\mathrm{P}<0.001)$ between planting date and mulching method on vine length of yam irrespective of variety. Furthermore, significant interaction $(\mathrm{P}<0.001)$ was observed between planting date and variety; mulching method and variety; and planting, mulching method and variety on number of leave and LAI of yam in both trials. All three varieties responded in the same way to planting date and/or mulching treatment, hence factorial effects of planting date $\mathrm{x}$ mulching method, planting date $\mathrm{x}$ variety, mulching method $\mathrm{x}$ variety and planting date $\mathrm{x}$ mulching method $\mathrm{x}$ variety were generally not statistically significant.

\section{CONCLUSION}

From this study, it is obvious that partitioning of the growing season into different phenological stages for investigating crop - water relationship using rainfall potential evapotranspiration model will allow the determination of the extent to which the water availability 
Table 5. Interactive effect of variety, planting date and mulching method on growth on yam during the 2017 cropping season.

\begin{tabular}{|c|c|c|c|c|c|c|c|c|c|}
\hline Factor & $\begin{array}{c}\text { Emergence } \\
(\%)\end{array}$ & $\begin{array}{c}\text { Vine } \\
\text { elongation } \\
(\mathrm{cm})\end{array}$ & $\begin{array}{c}\text { No. of } \\
\text { branches }\end{array}$ & No. of leaves & No of roots & $\begin{array}{c}\text { Vine } \\
\text { diameter } \\
(\mathrm{cm})\end{array}$ & $\begin{array}{l}\text { Branch } \\
\text { length } \\
(\mathrm{cm})\end{array}$ & $\begin{array}{l}\text { Root length } \\
(\mathrm{cm})\end{array}$ & LAI \\
\hline \multicolumn{10}{|l|}{ Prob. Level P } \\
\hline Date x mulch & 0.086 & $<0.001^{\star}$ & 0.579 & $<0.001^{\star}$ & 0.380 & 0.392 & 0.068 & 0.696 & $<0.001^{\star}$ \\
\hline Datex variety & $<0.001^{\star}$ & 0.915 & 0.426 & $<0.001^{\star}$ & 0.749 & 0.163 & 0.298 & 0.969 & $0.007^{\star}$ \\
\hline Mulch x variety & 0.611 & 0.465 & 0.999 & $<0.001^{\star}$ & 0.468 & 0.514 & 0.304 & 0.429 & $<0.001^{\star}$ \\
\hline Date $\mathrm{x}$ Mulch $\mathrm{x}$ variety & 0.073 & 0.613 & 0.152 & $<0.001^{\star}$ & 0.601 & $0.053^{\star *}$ & 0.284 & 0.750 & $<0.001^{\star *}$ \\
\hline
\end{tabular}

${ }^{\star}$ Significant at $\mathrm{P}<0.01 .{ }^{*}$ Significant at $\mathrm{P}<0.05$

Table 6. Interactive effect of variety, planting date and mulching method on growth of yamduring the 2018 cropping season.

\begin{tabular}{|c|c|c|c|c|c|c|c|c|c|}
\hline Factor & $\begin{array}{c}\text { Emergence } \\
(\%)\end{array}$ & $\begin{array}{l}\text { Vine } \\
\text { elongation } \\
(\mathrm{cm})\end{array}$ & $\begin{array}{c}\text { No. of } \\
\text { branches }\end{array}$ & No. of leaves & No of roots & $\begin{array}{c}\text { Vine } \\
\text { diameter } \\
(\mathrm{cm})\end{array}$ & $\begin{array}{l}\text { Branch } \\
\text { length } \\
(\mathrm{cm})\end{array}$ & $\begin{array}{l}\text { Root length } \\
\qquad(\mathrm{cm})\end{array}$ & LAI \\
\hline \multicolumn{10}{|l|}{ Prob. Level P } \\
\hline Date $\mathrm{x}$ mulch & 0.344 & $<0.001^{\star}$ & 0.786 & $<0.001^{\star}$ & 0.895 & 0.593 & 0.551 & 0.425 & $<0.001^{\star}$ \\
\hline Date $\mathrm{x}$ variety & 0.664 & 0.095 & 0.626 & $<0.001^{\star}$ & 0.888 & 0.508 & 0.468 & 0.605 & 0.211 \\
\hline Mulch $\mathrm{x}$ variety & 0.970 & 0.048 & 0.869 & $<0.001^{\star}$ & 0.865 & 0.523 & 0.827 & 0.703 & $<0.001^{\star}$ \\
\hline Date $\mathrm{x}$ Mulch $\mathrm{x}$ variety & 0.621 & 0.252 & 0.694 & $<0.001^{*}$ & 0.538 & 0.904 & 0.963 & 0.508 & $0.043^{* *}$ \\
\hline
\end{tabular}

${ }^{\star}$ Significant at $\mathrm{P}<0.01 .{ }^{* *}$ Significant at $\mathrm{P}<0.05$.

Table 7. Interactive effect of variety, planting date and mulching method on yield and yield characteristic of yamduring the 2017 cropping season.

\begin{tabular}{|c|c|c|c|c|c|}
\hline Factor & $\begin{array}{l}\text { Tuber length } \\
(\mathrm{cm})\end{array}$ & $\begin{array}{l}\text { Tuber diameter } \\
(\mathrm{cm})\end{array}$ & $\begin{array}{c}\text { Tuber weight } \\
(\mathrm{kg})\end{array}$ & No of tuber & $\begin{array}{l}\text { Harvest yield } \\
\text { (ton/ha) }\end{array}$ \\
\hline \multicolumn{6}{|l|}{ Prob. Level P } \\
\hline Date $\mathrm{x}$ mulch & 0.132 & 0.330 & 0.316 & $0.032^{* *}$ & $<0.001^{\star}$ \\
\hline Date $\mathrm{x}$ variety & 0.871 & 0.665 & 0.693 & 0.077 & 0.066 \\
\hline Mulch x variety & 0.224 & 0.150 & 0.080 & 0.100 & $0.025^{\star *}$ \\
\hline Date $\mathrm{x}$ Mulch $\mathrm{x}$ variety & 0.441 & 0.719 & 0.950 & 0.596 & 0.758 \\
\hline
\end{tabular}

${ }^{*}$ Significant at $\mathrm{P}<0.01 .{ }^{* *}$ Significant at $\mathrm{P}<0.05$.

Table 8. Interactive effect of variety, planting date and mulching method on yield and yield characteristic of yam during the 2018 cropping season.

\begin{tabular}{|c|c|c|c|c|c|}
\hline Factor & $\begin{array}{l}\text { Tuber length } \\
(\mathrm{cm})\end{array}$ & $\begin{array}{l}\text { Tuber diameter } \\
\qquad(\mathrm{cm})\end{array}$ & $\begin{array}{c}\text { Tuber weight } \\
(\mathrm{kg})\end{array}$ & No of tuber & $\begin{array}{l}\text { Harvest yield } \\
\text { (ton/ha) }\end{array}$ \\
\hline \multicolumn{6}{|l|}{ Prob. Level P } \\
\hline Date $\mathrm{x}$ mulch & 0.296 & 0.094 & 0.329 & 0.261 & 0.077 \\
\hline Date $\mathrm{x}$ variety & 0.313 & $0.047^{\star \star}$ & 0.268 & 0.213 & 0.266 \\
\hline Mulch x variety & 0.407 & 0.305 & 0.257 & 0.605 & 0.266 \\
\hline Date $\mathrm{x}$ Mulch $\mathrm{x}$ variety & 0.305 & 0.501 & 0.156 & 0.291 & 0.183 \\
\hline
\end{tabular}

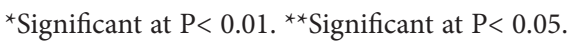


will satisfy water requirement of crops during the different phenological stages. Such information helps in the design of appropriate technological/ agronomical devices that will maximize beneficial effects. For instance, a balanced water supply during critical water requirement such as active growth period of vine and leaf development, tuber initiation and bulking; the most critical stages being at tuber initiation and bulking will lead to an effective yield. On the other hand, too little or excess water supply is detrimental, as it might lead to poor development and growth of the crop and consequently low yield. Generally early planting particularly when accumulated difference between $\mathrm{P}$ and $0.5 \mathrm{PE}$ where comparatively low $\{\Sigma(\mathrm{P}-0.1 \mathrm{PE}) \leq 10 \mathrm{~mm}\}$ gave a better yield as compared to later. Hence, for effective yam production in Southwestern Nigeria, farmer's must not delay planting until the accumulated difference between $\mathrm{P}$ and $0.1 \mathrm{PE}$ exceed $10 \mathrm{~mm}$. Furthermore, there was every indication that mulching significantly improved the emergence and development of yam setts and increased tuber yield and also grass mulch has significantly lower produced higher yield than the polythene mulch. However, both mulches have the physical effect of reduction of nutrient losses by surface erosion and leaching and also checks weed growth.

Also judging from the duration of the period of effective water availability, rainfall during the moist period, extreme lateness of onset of rainfall and water requirement by each of selected yam varieties, the production potential of some variety such as Efuru and Iseosi can be encouraged in the study area.

\section{REFERENCES}

Anthony, A. M and Ben K. B., 2018. Yam plant growth and tuber yield response to ex-situ mulches of moringa oleifera, chromolaena odorata and panicum maximum under three natural fallow aged systems. Annals of Ecology and Environmental Science, 2(3): 7-14.

Audu, E.B., 2012. A Descriptive Analysis of Rainfall for Agricultural Planning in Lokaja Local Government Area of Kogi State, Nigeria. Interternational Journal of Science Technology 2(2): 850-854.

Bello, N.J., 2000. Application of rainfall- potential evapotranspiration model for the determination of optimum planting date of maize (Zea mays) in a tropical wet and dry climate.Journal of Agricultural sciences. 70 (7): 437-400.

Bhandari, G., 2013. Effect of Precipitation and Temperature Variation on the Yield of Major Cereal in
Dadeldhura District of far Western Development Region, Nepal, International. Journal of Plant Animal Environmental Science 3(1): 247-255.

Cocheme, J. and Franquin, P., 1967. An agroclimatological survey of a semi arid area in South of the Sahara. WMO Technical note No. 86, Geneva.

CROPWAT., 2009. CROPWAT for windows, An FAO software, version 8.0. http://www.fao.org/nr/ water / infores databases cropwat.html

Deichmann, U., and Eklundh, L., 1991. "Global Digital Data Sets for Land Degradation Studies: A GIS Approach." GRID Case Study Series 4. United Nations Environment Programme, Global Environmental Monitoring System and Global Resource Information Database, Nairobi.Accessed February 2006. [http://geodata.grid.unep.ch/].

Doorrenbos, J. and Pruitt, W.O., 1984. Guidelines for predicting crop water requirements. Food and Agricultural Organization. Irrigation and Drainage paper No. 24. Rome: FAO.

FAO., 1977. Food and Agriculture Organization. Irrigation and Drainage Paper No 24, Rome: FAO

Gbadebor, P.V., 2006. The climate, the soils and the West African traditional farmers. AgroEcosystem Bull. 4: 12-17.

Gidey, E., O. Dikinya, R. Sebego, E. Segosebe, and A. Zenebe., 2018. Analysis of the long-term agricultural drought onset, cessation, duration, frequency, severity and spatial extent using vegetation health index (VHI) in Raya and its environs, northern Ethiopia. Environmental Research System 7 (13). https://doi. org/10.1186/s40068-018-0115-Z.

Hulugalle, N.R. and Lal, R., 1986. Soil water balance in intercropped maize and cowpea grown in a typical hydromophic soil Western Nigeria. Agronomy Journal 77: 86-90.

Hunt, R. 1978. Plant Growth Analysis. The Institute of Biology. Studies in Biology. Edward Arnold (Pub.) Ltd.96: 8-38.

International Institute of Tropical Agriculture (IITA)., 1995. Yam research at IITA: 1971-1993. IITA Ibadan, Nigeria, 38pp.

International Institute for Tropi-cal Agriculture (IITA),, 2009. Yam (Dioscorea species). Available at: http:// www.iita.org/yam. [Accessed: 15. March 2014].

International Institute for Tropi-cal Agriculture (IITA)., 2013. Healthy yam seed production. IITA Publications. Retrieved from IITA Website http://www.iita. org/publications

Inyang, E.U., 2005. An evaluation of tillage and storage systems applied by traditional root crop farmers in Cameroon. Agriculture and Envroment.Journal., 7(2): 15-22. 
Kutugi, A.D., 2002. Comparative analysis between indigenous and modern tillage practices in the production of Dioscorearotundataand Dioscoreacayenensisin the middle belt of Nigeria. Journal of Agriculture Environ., 2(1): 53-66.

Maikasuwa, M. A. and Ala, A. L. 2013. Determination of profitability and resource-use efficiency of yam production by women in Bosso local government area of Niger State, Nigeria. European Scientifi c Journal, 9(16): 196-205.

Mulebeke,R..Kironchi.G,.andTenywa, M. M., 2010. Enhancing water use efficiency of cassava and sorghum based cropping systems in drylands. Second RUFUROM biennial meeting, 20-24 September, 2010, Entebbe, Uganda http://news.mak.ac.ug/documents/RUFORUM/Mulebeke.pdf

Nahanga Verter and Věra Bečvářová (2015). Analysis of yam production in Nigeria. Acta Universitatis Agriculturae Et Silviculturae Mendelianae Brunensis., 63(2): 659-665.

Odjugo, P.A.O., 2008. The effect of tillage systems and mulching on soil microclimate, growth and yield of yellow yam (Doiscoreacayenensis) in Midwestern Nigeria. African Journal of Biochemistry. 7(24): 4500-4507.

Ofori, E.Oteng-Darko, P, Berchie, N. J., Nimako, F. O., Yeboah, S. and Owusu, D. E ., 2014. Monitoring of soil moisture regime and water use efficiency under maize cowpea. International Journal of Current Microbiology Applied Science. 3(10): 837-848.

Okoh, C.A., 2004. The effect of mulching on soil physicochemical properties and the yield of White Yam.Tropical Journal of Root Tuber Crops. 4(2): 24-31.

Olasantan,F.O, 2007. Effect of population density and sowing date of pumpkin on soil hydrothermal regime, weed control and crop growth in a yam pumpkin intercrop. Experimental Agriculture 43: 365380.

Olasantan, F.O., 1999. Effect of mulching on soil temperature and moisture regime and emergence, growth and yield of white yam in western Nigeria. Soil and tillage research 50: 215-221.

Shiru, M.S., S. Shahid, N. Alias, and E.S. Chung. 2018. Trend analysis of droughts during crop growing seasons of Nigeria. Sustainability 10(871): 1-13. https:// doi.org/10.3390/ su10030871.

Susha, L. S.U., Singh, D. N. and Maryam, S. B., 2014. A critical review of soil moisture measurement. Measurement 54: 92-105.

Tiamiyu, S.A., J.N. Eze, T.M. Yusuf, A.T. Maji, and S.O. Bakare. 2015. Rainfall variability and its effect on yield of Rice in Nigeria. International Letters of Natural Sciences 49: 63-68.
Um, M., Y. Kim, D. Park, and J. Kim. 2017. Effects of different reference periods on drought index estimations from 1901 to 2014. Hydrology and Earth System Sciences 21: 4989-5007.

Yanmin, Y.,De Li, L.,Muhuddin, A., Garry, O.,Ian, M.,Yonghui, Y., 2015. Water use Efficiency and crop water balance of rain-fed wheat in a semi-arid environment: sensitivity of future changes to projected climate changes and soil type. Theoretical and Applied Climatology lDOI 10.1007/s00704-015-1376-3.

Zaknayiba, D. B. and Tanko, L. 2013. Costs and returns analysis of yam production among small scale farmers in Karu local government area, Nasarawa State, Nigeria. PAT, 9(1): 73-8. 